\title{
Jie Dong* \\ Language and globalization revisited: Life from the periphery in COVID-19
}

https://doi.org/10.1515/ijsl-2020-0086

Received September 9, 2020; accepted November 19, 2020

Abstract: This short paper discusses language and globalization in the context of COVID-19. The pandemic has important impacts on people across the globe, and in particular the absence of face-to-face interaction results in new forms of communication and may lead to new ways of language change. This paper revisits sociolinguistics and globalization, and discusses challenges brought about by COVID-19 and its containment measures. The pandemic generates particularly discourses, especially from those who are affected the most. This paper includes a vignette of such discourses to show that mobility and inequality remain key issues in the current stage of globalization.

Keywords: globalization; digitalization; pandemic discourses; mobility; inequality; COVID-19

\section{Introduction}

Globalization has been around for quite some time - think of metaphors such as "a global village", "the world is flat" - penetrating borders and infiltrating every corner of life. However, the pandemic affects globalization in important ways: people across the world have been more or less "immobilized" and social distancing becomes a new norm. Economists see the virus as highly global itself, but disrupting global supply chains, stopping international travel and migration, and introducing a climate of uncertainty among peoples. Sociologists observe that nationalist narratives are on the rise as nation-states revive their power through implementing border closure and other mitigation measures (e.g. Appadurai 2020; Yaya et al. 2020).

In languages studies, researchers argue that the pandemic challenges linguistic diversity, multilingual communication and negatively affects linguistic minorities

*Corresponding author: Jie Dong, Tsinghua University, Beijing, China, E-mail: dong-jie@mail.tsinghua.edu.cn 
across the world (e.g. Piller et al. 2020; Popiolek 2020; Tan 2020). The process of digitalization accelerates during the pandemic; however, international flows of people, goods and capital are plummeting, which can hit socially marginalized groups hardest. While it is premature to tell what globalization will become, we have seen that the pandemic has had a major impact on the global economy, health care and many other sectors. How does the pandemic affect language? What will happen to language when people increasingly rely on online communication?

\section{A sociolinguistics of globalization}

Blommaert (2010) argued for a new paradigm of sociolinguistics that could capture the complex relations between language and globalization, a paradigm he called "sociolinguistics of mobility". In this new paradigm, language was understood as dynamic, "in-motion" and fundamentally changed by globalization, and the sociolinguist's job was not to study "language and society", but "language in society", or more precisely "changing language in a changing society" (2010:12, italic in original). Blommaert (2010) was among an expanding body of literature that explores language and globalization (e.g. Calvet 2006; Collins et al. 2009; Coupland 2010; de Swaan 2001). Issues of inequality and mobility are central to sociolinguistic studies of globalization. A norm is a set of explicit or implicit rules of how language should be used, and linguistic practices are "normative" when they are in line with the established norms. In globalization, however, they can be transferred and transported, "upscaled" or "downscaled", and the norms from one level of locality are projected onto the norms from another level. In rescaling of norms, those that are more mobile that is, more able to project to other levels - are valued higher (e.g. British or US standard English), and those that are less mobile - valid at particular levels - are valued lower (e.g. Indian or Nigerian English).

Blommaert (2010) demonstrated that globalization had a clear sociolinguistic dimension. It was important to remember that this conceptualization of language and globalization had been developed in the heyday of globalization and no one could assume that it will go on indefinitely.

\section{Language and globalization in COVID-19}

With the lockdowns and quarantine measures, however, globalization faces multiple challenges. In language studies, the first challenge could be the large 
amount of rapidly emerging neologisms, and relating to this is how to make this scientific and medical language beneficial to multilingual, indigenous and minority communities (e.g. OUP 2020). As the virus spreads to densely populated cities and linguistically diversified regions, the tasks of making crucial information available to affected communities are urgent and, in solving these problems, translation plays a key role in facilitating multilingual crisis communication (Zhang and $\mathrm{Wu}$ 2020).

Another challenge is the spread of disinformation, such as on hygiene and physical distance (Tan 2020). Access to accurate life-saving information is vital and the fight against disinformation entails not only strict verification procedures but also awareness of the linguistic and stylistic features of fake news. One remarkable feature of COVID-19 disinformation is to play into people's fear. If fear is excessive, it can have detrimental effects both at the individual level and at the societal level, such as anxiety and xenophobia (Mertens et al. 2020). Other linguistic features include lexical richness, the amount of quoted content and uppercase letters, stylistic features such as coherence, and visual features such as image clarity and relevance of images (Reddy et al. 2020).

Limited international travel means less language contact in face-to-face manner, but this may not diminish linguistic diversity as multilingual communication strives in the online environments. Zoom ${ }^{1}$ is widely used not only for business meetings, but also for purposes such as family chats and online classes (van der Marel and Guinea 2020). In education, teaching and learning activities are held in virtual forms, accelerating digitalization, which was already on the rise before the pandemic (Dong and Blommaert 2016). Language teaching could be disrupted as it requires direct interaction between teachers and students, but reports show that the amount of real-time online language classes is increasing remarkably and the valuation of leading online language learning enterprises is soaring during the pandemic (e.g. Yu 2020). While many celebrate online education as being equally accessible for the rural and the urban, the rich and the poor, the far and the near, it is important to be aware that not everyone can connect to the Internet, is computer literate, or has a quiet place for learning.

\section{Globalization from below}

The same applies to those whose jobs cannot go remote. Research shows jobs that can be performed from home tend to be well-paid, white-collar occupations in big cities, while occupations such as farming, factory jobs, waiting staff (hospitality in

1 Zoom is a US-based company providing video-conference services. 
general) do not easily swift to remote working (Dingel and Neiman 2020). Hobsbawm once said, "the impact of this globalization is felt most by those who benefit from least” (2007:3). And the current development of globalization is no exception.

COVID-19 generates particular discourses. Our research on how China's ruralurban migrant workers talk about their lives during the pandemic shows that, although China has managed to control the pandemic rapidly and effectively (Burki 2020), at the time of writing many migrant workers suffer from socioeconomic consequences. Globalization is characterized by interconnectedness and interdependence, and although Chinese factories have been reopened quite early, many orders are canceled or delayed because the pandemic slows down their international trading partners' demands. As my informant Ms. Tian (age 42, mother of two), who had worked for 20 years in factories told me, her factory would be closed soon.

I feel so bad to leave this job. The boss always pay us on time. With that pay, I can bring my children here and to send them to school. (Fieldnote08-11-T)

She did not know where to go, as other factories also suspended production or closed down. Now the best choice seemed to be returning to their hometowns, but this means a series of consequences.

What Tian faced was common for many Chinese internal labor migrants who were attracted to industrial manufacturing jobs. Many worked in factories that were fuelled by foreign investment, and they were deeply involved in and affected by globalization (Dong 2011, 2017). What Blommaert (2010) argued about inequality and mobility is still valid in the current stage of globalization, and changes at a global level penetrate all the way down to the lowest strata of the world system.

\section{5 “The end of globalization?"}

In the introductory chapter of Coupland (2010), he uses "The end of globalization?" as a section title, a question raised in the aftermath of 2008 global financial crisis. Coupland does not give a direct answer but his efforts in editing a volume of 29 papers on language and globalization show that he takes globalization seriously and uses it as an analytical framework in studying sociolinguistic phenomena. Since the time of the 2008 financial crisis, globalization has been intensified with wider use of smartphones and mobile computing, and new ways of using languages in SNSs are observed, documented and analysed (e.g. Androutsopoulos 2006; boyd 2014; Gardner and Davis 2013). For now, one could say that what we 
will have is a different kind of globalization, and it will be different for different people. The changes will challenge what we have understood about globalization, and what we have known about language in globalization.

\section{References}

Androutsopoulos, Janis. 2006. Multilingualism, diaspora, and the Internet: Codes and identities on German-based diaspora websites. Journal of Sociolinguistics 10(4). 520-547.

Appadurai, Arjun. 2020. Coronavirus won't kill globalization. But it will look different after the pandemic. Time. Available at: https://time.com/5838751/globalization-coronavirus/ (last viewed on 15 November 2020).

Blommaert, Jan. 2010. The sociolinguistics of globalization. Cambridge: Cambridge University Press.

boyd, danah. 2014. It's complicated: The social lives of networked teens. New Haven: Yale University Press.

Burki, Talha. 2020. China's successful control of COVID-19. The Lancet. Available from: https:// www.thelancet.com/journals/laninf/article/PIIS1473-3099(20)30800-8/fulltext (last viewed on 15 November 2020).

Calvet, Louis-Jean. 2006. Towards and ecology of world languages. Cambridge: Polity Press.

Collins, James, Steff Slembrouck \& Mike Baynham (eds.). 2009. Globalization and language in contact. London: Continuum.

Coupland, Nikolas (ed.). 2010. The handbook of language and globalization. Oxford: WileyBlackwell.

de Swaan, Abram. 2001. Words of the world: The global language system. Cambridge: Polity.

Dingel, Jonathan I. \& Neiman Brent. 2020. How many jobs can be done at home? Available from: https://brentneiman.com/research/DN.pdf (last viewed on 15 Nov 2020).

Dong, Jie. 2011. Discourse, identity, and China's internal migration: The long march to the city. Bristol: Multilingual Matters.

Dong, Jie. 2017. The sociolinguistics of voice in globalising China. London: Routledge.

Dong, Jie \& Blommaert Jan. 2016. Global informal learning environments and the making of Chinese middle class. Linguistics and Education 34. 33-46.

Gardner, Howard \& Katie Davis. 2013. The app generation: How today's youth navigate identity, intimacy, and imagination in a digital world. Yale: Yale University Press.

Hobsbawm, Eric. 2007. Globalization, democracy and terrorism. London: Little, Brown.

Mertens, Gaëtan, Lotte Gerritsen, Stefanie Duijndam, Elske Salemink \& Iris M. Engelhard. 2020. Fear of the coronavirus (COVID-19): Predictors in an online study conducted in March 2020. Journal of Anxiety Disorders 74. 1-8.

OUP. 2020. Covid-19 language hub. Oxford Languages. Available from: https://languages.oup. com/covid-19-language-resources/\#translations (last viewed on 15 Nov 2020).

Piller, Ingrid, Jie Zhang \& Li Jia. 2020. Linguistic diversity in a time of crisis: Language challenges of the COVID-19 pandemic. Multilingua 39(5). 503-515.

Popiolek, Kim. 2020. Researchers study how COVID pandemic is affecting language change. MUS Today Available from: https://msutoday.msu.edu/news/2020/researchers-study-howcovid-pandemic-is-affecting-language-change/ (last viewed on 15 Nov 2020). 
Reddy, Harita, Namratha Raj, Manali Gala \& Annappa Basava. 2020. Text-mining-based fake news detection using ensemble methods. International Journal of Automation and Computing 17(2). 210-221.

Tan, Kim Hua. 2020. 'Fear' in covid-19 fake news: A corpus-based approach. 3L: The Southeast Asian Journal of English Language Studies 26(2). 1-23.

van der Marel, Erik \& Oscar Guinea. 2020. Globalization after COVID-19. European Center for International Political Economy. Available from: https://ecipe.org/blog/globalization-aftercovid19/ (last viewed on 15 Nov 2020).

Yaya, Sanni, Otu Akaninyene \& Ronald Labonté. 2020. Globalisation in the time of COVID-19: Repositioning Africa to meet the immediate and remote challenges. Globalization and Health 16(51). 1-7.

Yu, Wenchi. 2020. Online English language learning in the time of COVID-19. Asian Society Available from: https://asiasociety.org/asia21-young-leaders/online-english-languagelearning-time-covid-19 (last viewed on 15 Nov 2020).

Zhang, Jie \& Yu Qin Wu. 2020. Providing multilingual logistics communication in COVID-19 disaster relief. Multilingua 39(5). 517-528. 